\title{
Marlowe and Shakespeare Cross Borders: Malta and Venice in the Early Modern World
}

\begin{abstract}
This essay deals with the worlds of early modern Malta and Venice, two distinctly nonEnglish locations, as depicted by Marlowe and Shakespeare. In particular, it considers the roles Jews played in The Jew of Malta and The Merchant of Venice. I argue that while Shakespeare is completely accurate in his depiction of the spirit of financial and mercantile adventurism and huge risk-taking that characterized early modern Venice, he does not fully reflect the tolerance that marked this early modern trading capital. Shakespeare bases his play on binaries and antagonistic opposition between the Jews and the Christians in Venice while Marlowe consciously resists painting his world in black and white. Marlowe's Malta is a melting pot, a location where boundaries and distinctions between Jew, Christian, and Muslim, and between master and slave, blur, and easy definitions and categorizations become impossible. In spite of borrowing many historical details of the Great Siege of Malta (1565), Marlowe refuses to end his play with the siege and its attendant grand narrative of heroic Christian troops defeating barbaric Turks and bringing about a decisive victory for the Christian world.
\end{abstract}

This essay deals with depictions of the worlds of early modern Malta and Venice, two distinctly non-English locations, by Christopher Marlowe and William Shakespeare. In particular, it considers the roles Jews played in The Jew of Malta (composed by Marlowe between 1581 and 1593) and The Merchant of Venice (composed by Shakespeare ca 1596-8). I shall first discuss the geographical and historical background of early modern Malta and its close association with the Jews before going on to Marlowe's depiction of it in his play. I will then follow the same process for Venice in connection with Shakespeare's play. I argue that while Shakespeare is completely accurate in his depiction of the spirit of financial and mercantile adventurism and huge risk-taking that characterized early

Shormishtha Panja (panjashormishtha@gmail.com) is professor of English at the University of Delhi. 
modern Venice, he does not fully reflect the tolerance and liberalism that marked this early modern trading capital. Shakespeare bases his whole play on binaries and antagonistic opposition between the Jews and the Christians in Venice while Marlowe consciously resists painting his world in black and white. ${ }^{1}$ Marlowe's Malta is a melting pot, a location where boundaries and distinctions between Jew, Christian, and Muslim, and between master and slave, blur, and easy definitions and categorizations become impossible. In spite of borrowing many historical details of the Great Siege of Malta (1565), Marlowe refuses to end his play with the siege and its attendant grand narrative of 'heroic' Christian troops defeating 'barbaric' Turks and bringing about a decisive victory for the Christian world.

\section{Malta: Muslims, Jews, and the Knights Hospitaller}

Malta was an archipelago in the central Mediterranean between Sicily and the North African coast, one of strategic importance because of its connection to the Italian city-states, to the Near East, to Palestine, and to North Africa. According to Cecil Roth, the ancient name for Malta - Melita — is said to be derived from the Hebrew root 'malat', meaning to escape. ${ }^{2}$ The most famous Jew associated with Malta is Paul of Tarsus, who in $62 \mathrm{CE}$ was on his way to Italy with other prisoners when he was shipwrecked and forced to stay in Malta for three months. As Roth puts it, 'Paul could as yet perhaps still be reckoned a Jew'.

Until the fifteenth century, Malta followed the more immediate fortunes of nearby Sicily, being ruled successfully by the Arabs (who left a strong effect on the language, a combination of North African Arabic and a Sicilian form of Italian), the Normans (who advanced Malta's legal and governmental structures), and a succession of feudal lords. In 1530 it was ceded to the order of the Hospital of St John of Jerusalem, the Knights Hospitaller, a religious and military order of the Roman Catholic Church. In 1522 the Knights had been defeated by the Turks and were compelled to leave their fortress at Rhodes. They had lived in exile for eight years. During this period, the grand master Villiers de l'Isle Adam visited the European rulers, including England's Henry VIII, with requests for assistance. His pleas met with little success until the Emperor Charles V agreed to donate to the Knights on the island of Malta. As a condition of this gift, the Knights would have to defend the islands against the Turks and make it a 'bulwark of Christendom. ${ }^{4}$ The grand master of the Knights was the renowned Jean de la Valette, the order's most illustrious leader, commanding the troops against the Turkish onslaught in the Great Siege of 1565, which I shall discuss shortly. 
Their Hospitaller duties, nominal at best, were overtaken by their military skirmishes against the Turks by the sixteenth century. ${ }^{5}$

The Knights' whole reason for existence was hostility between the Muslim world and the Christian world, but the means they used to fan disorder and build their financial strength had very little to do with Christian ethics. They ransacked the sea vessels of the Turks and the other non-Christian powers in ways 'hardly distinguishable from piracy'. ${ }^{6}$ Shipping was 'preyed upon indiscriminately' and all goods and occupants were brought to Malta to be sold, 7 a fact of immense significance for Marlowe's play. In 1565, during the grand mastership of La Valette, a Turkish fleet laid siege to Malta. This event became known as the Great Siege. Many European powers followed the Great Siege, one of the best-known episodes in the history of Malta, since the fall of Malta would make Sicily and the rest of Italy vulnerable to the Turks. ${ }^{8}$ After the Turks were defeated, the new capital city of Valletta, named after the grand master, with its forts and grand palaces and fortifications, was a sign of that victory. As Lisa Hopkins observes, even two hundred years after the siege 'Voltaire could still say "Rien n'est plus connu que le siège de Malte" (nothing is better known than the siege of Malta)'.?

After the Great Siege of 1565, Malta grew in power and wealth, owing mainly to Maltese maritime adventures against the Turks. The Knights left the island an architectural and artistic legacy. Despite little economic and social contact between the Knights and the Maltese, the Knights imprinted their cosmopolitan character on Malta and its people. Malta, as Hopkins notes, became a 'stopping post where Moslem, Jew and Christian meet. ${ }^{10}$ Commenting similarly, Stephen Greenblatt writes: 'the Jew buys a Turk at the Christian slave market. Such is the triumph of [Maltese] civil society.'11

What about the position of Jews in Malta? According to Roth, Malta bore a 'Semitic imprint' from the days of the pre-Christian Phoenician traders. ${ }^{12}$ As a result of Malta's proximity to both the Christian and the Muslim worlds, Jewish traders 'found in this entrepot of Mediterranean commerce a useful center for their activities. ${ }^{13}$ The Jews were, paradoxically, both persecuted and powerful. ${ }^{14}$ They were affluent because of their shrewd financial dealings and their sharp financial acumen, yet were often subjected to arbitrary and whimsical taxes and fines as well as periodic eviction notices and orders to convert. Roth also writes of the peculiar vulnerability of the Jews in this region, mistrusted as they were by both Christian and Turk. As Barabas puts it, 'Malta hates me, and, in hating me, / My life's in danger' (5.2.31-2). ${ }^{15}$

The Jews of Malta were taxed and forced to give up their property. In Marlowe's play, the Christian governor of Malta, Ferneze, immediately passes on to 
the Jews the tribute money Calymath levied on Malta. They are to give up half of all they own or convert to Christianity (1.2). Roth points out how the Jews, when banished from Malta in 1492, had to 'indemnify the Crown for the loss of the special tributes which had hitherto been received from them'. ${ }^{16}$ The Jews had to pay poll tax and help with the fortification expenses. Though they were expelled, they could not take with them any money, gold, silver, precious stones, or livestock, as that would deplete Malta's resources. ${ }^{17}$ Faced with such unfair terms, the Jews understandably concealed precious items rather than give them up, as does Barabas. Neophytes could purchase the privilege of baptism by surrendering forty-five per cent of their property. The Jews had been approached for this purpose during the reign of Ferdinand of Aragon, before the time of the Knights Hospitaller. ${ }^{18}$ The Knights regarded the Jews as even more dangerous than the Turks because of their espionage skills, and indeed the Jews of Malta did conspire against both Turks and Christians. ${ }^{19}$ This climate of suspicion, betrayal, and lack of trust worked both ways, however: the Knights and monks were a menace to the Jews. Roth quotes from a 1565 traveller's account lamenting the fact that the monks in particular 'are exceeding evil to the Jews'; they 'are still to-day a snare and a trap for the Jews. ${ }^{20}$

\section{The Jew of Malta: 'who amongst 'em knows not Barabas?'}

Marlowe's play, from its beginning, presents Malta as a worldly, cosmopolitan milieu. First, Barabas, unlike Shakespeare's Shylock, is a wealthy merchant and not a moneylender. He is not seen as an outsider, a minority figure, or an infidel, but is very much assimilated into the multicultural environment of Malta. 'Go tell 'em the Jew of Malta sent thee, man', he boasts to the merchant: 'Tush, who amongst 'em knows not Barabas?' (1.1.67-8). Barabas's opening speech refers to his equal degree of comfort and familiarity with Persia, the Samnites (Southern Italy), Uz (bordering Palestine), Arabia, Spain, Greece, India, the Moors, Egypt, Alexandria, and 'Candy-shore' (Crete). Just as he will later boast that his shirt is a 'present from the Great Cham' (the Emperor of Tartary) (4.4.91) and that his goods will travel to Alexandria, Florence, Venice, Antwerp, London, Seville, 'Frankfort, Lubeck, Moscow' (4.1.74-5), he now refers proudly to his cargo of 'Spanish oils and wines of Greece' and 'Bags of fiery opals ... grass-green emeralds' (1.1.5, 25-6), which he has to keep safe from the 'galleys of the Turk'. Cosmopolitanism is not limited to the protagonist of the play. Just as Barabas boasts that 'I learn'd in Florence how to kiss my hand' (2.3.23) and impersonates a French musician with élan as part of his plan to dupe the courtesan Bellamira and his slave Ithamore, 
Bellamira in turn laments the absence of Venetian merchants and 'rare-witted gentlemen' from Padua who were earlier her customers (3.1.7).

The Turks preyed on Maltese ships and the sultan was seeking a route to Venice through the Adriatic. When the Spanish ships land in Malta their foreignness is not striking, as in The Merchant of Venice. They are all united by one desire profit - and all engaged in one activity: trade. Marlowe quickly establishes a mutually beneficial system of exchange, as Ferneze promises the Spanish a market to sell their slaves if the Spanish help the Maltese against the Turks.

Summarizing the general attitude towards the monks in the play, Ithamore calls the friars 'two religious caterpillars' (4.1.22). The monks were a nuisance to the Jews. Apart from quoting the chronicler mentioned earlier who says that 'The monks of Malta are still to-day a snare and trap for the Jews' in his account of the attack of the Turks on Malta in $1565,{ }^{21}$ Roth also quotes the sixteenth-century historian and physician Joseph haCohen's Vale of Tears (a 'heartbreaking' account in Roth's words), which describes an incident in 1552 when the monks of Rhodes captured seventy Jews on board a ship coming from Salonica, and the Jews had to 'pay for the ransom of their souls to the miserable monks' before they were allowed to continue on their voyage. ${ }^{22}$ Even at the beginning of the seventeenth century historical accounts proclaim that the 'monks of Malta are exceeding evil to the Jews. ${ }^{23}$

Marlowe's play bears this picture out, with the addition that Barabas does not take the cruelty lying down and is adept at wreaking revenge. Both friars in the play, Friar Barnardine and Friar Jacomo, are figures of perfidy. Friar Barnardine's response to Barabas's daughter Abigail's dying words, 'And witness that I die a Christian!', is a callous 'Ay, and a virgin too; that grieves me most' (3.6.41). The Friars violate religious laws when they betray Abigail's dying confession in order to trick Barabas into conversion so that they can grab his wealth. ${ }^{24}$ Friar Barnardine does not care about the nuns who have been poisoned; he is more interested in saying to Friar Jacomo, 'help me to exclaim against the Jew' (3.6.46). For his part, Barabas says about the monks, 'now the nuns are dead, / They'll die with grief' (4.1.16-17), referring not to their compassion but to their overwhelming and indiscriminate sexual appetite. Friar Barnardine does not even bother to bury the nuns who have been poisoned. Friar Jacomo and Friar Barnardine fight over whose order will get Barabas's wealth, with Friar Jacomo exclaiming, 'O happy hour, wherein I shall convert / An infidel, and bring his gold into our treasury!' (164-5). The focus of the monks is clearly wealth and women and not religion unless religion serves as a gateway to riches and sex. 
Another important aspect of Marlowe's representation of Malta is the significance given to the slaves. Till the last day of the rule of the Knights, Malta was an important European refuge of slave traffic; slaves contributed to the economy of forced labour on Malta. The slaves were not just persons of colour or impoverished wanderers but whoever happened to be travelling in the captured vessel, whatever their race, religion, sex, or economic status. ${ }^{25}$ Jews and other nomads were often found on ships, and, if so, captured and sold as slaves. The slaves taken from the captured Turkish galleys gave labour to erect new fortifications and restore damaged ones, besides providing hands to transport victuals and water and to get rid of the dead bodies. ${ }^{26}$

Roth quotes the account of an English traveller to Malta: 'Jews, Moors and Turks are made slaves here, and are publickly sold in the markets'. ${ }^{27}$ The account gives the story of a rich Jew sold in market who, believing himself to be free, struck the merchant who bought him. For this act his beard and hair were chopped off, and he was 'bastinado'd with 50 blows. ${ }^{28}$ Appropriately, racial variety exists in Marlowe's slave market, which consists of Moors, Turks, and Jews. The Spanish Captain Del Bosco brings Greeks, besides Moors and Turks, to the slave market.

Marlowe gives the slave Ithamore a crucial role, moreover - he is the only confidante of the suspicious Barabas (apart from Barabas's daughter Abigail), and one who dares to try to outwit him. Ithamore's rapid rise in the social scale reflects the mobility of Malta's slaves who could become, as did the Jews, slaves because their wealth was confiscated, or could, through conversion to Christianity, marriage, and business acumen, be integrated within mainstream Maltese society. ${ }^{29}$

One of the most crucial aspects of Marlowe's Malta is its ethical or non-ethical homogeneity. Sameness rather than difference dominates here. Marlowe does not set up moral dichotomies between European and non-European or between Christian and Semitic/Jew, as does Shakespeare, as I argue later in this essay. ${ }^{30}$ Integrated into the homogeneous culture of mercantilism and overriding greed, Barabas is not the exception but the rule in Malta. Those around him, both Christian and Muslim, differ only in degree and not kind in their rapacious and unscrupulous love of gold. The play exposes the hypocrisy of Ferneze's so-called Christian ethics at his very first appearance when he pretends that asking the Jews to pay the tax imposed on Malta by the Turkish 'Selim' Calymath is justified because they are infidels:

For through our sufferance of your hateful lives,

Who stand accursed in the sight of heaven,

These taxes and afflictions are befall'n 
Ferneze makes the tax sound like a blight sent from heaven rather than his own, mortal and political, decision. Later, after virtually stealing Barabas's wealth in the form of taxes, he piously claims that 'covetousness, $\mathrm{O}$, 'tis a monstrous sin!' (128) and squeamishly distances himself from violence: 'To stain our hands with blood / Is far from us and our profession' (148-9). This character is, of course, the same Ferneze who will tumble Barabas into a boiling cauldron and kill him. Ferneze's doublespeak does not dupe Barabas himself, who remarks on the Christians' 'unseen hypocrisy' and their use of religion for nefarious purposes (304). Ferneze breaks his agreement with the Turks and keeps the Jews' money, on advice of a Spanish man who wants to sell Turkish slaves. His pious declaration, 'Honor is bought with blood, and not with gold' (2.2.56), is punctured with the setting up of a profitable slave market immediately afterwards. ${ }^{31}$ When Ferneze welcomes the Basso and asks after Calymath, ${ }^{32}$ the Basso, unlike the hypocritical Ferneze, openly confesses that the wind that blows him to Malta is 'The wind that bloweth all the world besides, / Desire of gold' (3.5.3-4). 'This is the life we Jews are us'd to lead', Barabas remarks nonchalantly, after crossing and double crossing both Christian Ferneze and Muslim Calymath, 'And reason too, for Christians do the like' (5.2.117-18). Barabas's words bear ironic fruit when Ferneze pretends to go along with his scheme of capturing Calymath only to hoist Barabas with his own petard. Ferneze's hypocrisy remains unchanged to the end. He tumbles Barabas into the boiling cauldron and piously proclaims that 'due praise' should 'be given' for such deliverance, 'Neither to Fate nor Fortune, but to Heaven' (5.5.130-1). Barabas's muttered warning to himself after tricking Ferneze and Calymath and becoming governor of Malta - 'And, since by wrong thou gott'st authority, / Maintain it bravely by firm policy; / At least, unprofitably lose it not' (5.2.36-8) - expresses a Machiavellianism that is not peculiar to him but is shared by all the major male characters of the play, particularly those in positions of authority. The end justifies the means; the seemingly beneficial 'policy' disguises the unscrupulous means; and the need for profit is always the ruling motive. ${ }^{33}$

Marlowe's play was written between 1581 and 1593 (the year he was killed), so the Great Siege that took place in 1565 was no doubt fresh in European and English memory. Lisa Hopkins points out that Marlowe includes many minor details of the siege. The confiscation of Barabas's house for a nunnery seems to reflect the convent installed in the ruins of a Jewish residence. Barabas's blowing up of the house containing the Turkish soldiers, too, mirrors the collapsing wall. ${ }^{34}$ Hopkins quotes from Stanley Fiorini's 'Malta in 1530': 
It appears from a notarial deed of 2 June 1496, that the monastery of St Scolastica had just been founded ... The monastery was then occupying what had once been the synagogue of the Jews that had been expelled from the island only four years earlier. The monastery of St Scolastica eventually moved to Birgu. Their short stay at Mdina is fairly well documented. On several occasions they sought help from the Università, as in 1516 when the city wall had collapsed, pulling down part of the monastery with it. 35

This particular incident is also reminiscent of two other significant events which had an important effect on Maltese history: the destruction of the bastion of Castile by the Turks during the Great Siege, 36 and, after it, Grand Master Jean de la Valette's 'attempt to forestall a second invasion planned by the Turks for the year after the Great Siege by having his spies in Constantinople set the arsenal on fire by blowing up magazines'. ${ }^{37}$ Jean de la Valette's decision to poison the wells on Marsa used by the Turkish forces during the Great Siege no doubt inspired Barabas's poisoning of the convent's food. ${ }^{38}$

Surprisingly, given all these similarities, Marlowe pointedly avoids the choice of the Great Siege as a climax for his play. Ferneze does not defeat Barabas in a grand show of the heroic triumph of the Christian faith over the infidel, whether Jewish or Turkish. The play thus departs from the popular narrative about the Great Siege and the role of the Knights Hospitaller. That grand narrative cleverly avoided little details of the Knights' treachery and deception such as using towns and citizens as scapegoats, poisoning drinking water, and asking volunteers, including Jews, to risk immediate death. The Knights lauded as heroes because of the successful defeat of the Turks were not loath to use remarkably un-Christian means to achieve their end. Marlowe seems deliberately to resist the dramatic climax of the Great Siege because it would run against his conviction of the lack of discrimination between Christian and Muslim and Jew when it came to the lust for gold and power. It would annul the showcasing of similitude as in the ubiquitousness of perfidy and instead build up false polarities of right and wrong, of virtuous protagonist and evil antagonist, of good Christian and bad Jew or Turk, that Marlowe takes such pains to avoid in his depiction of Malta. ${ }^{39}$

\section{Venice: Centre of the World Economy}

Immanuel Wallerstein writes of the rupture in European economic thinking that occurs in 1500 and brings about an 'emphasis on creation of a capitalist world-system, as distinct from other forms of economies'. ${ }^{40}$ This shift 'involved 
the transformation of a particular redistributive or tributary mode of production, that of feudal Europe (Braudel's "economic Ancien Regime") into a qualitatively different social system. ${ }^{41}$ Since then, according to Wallerstein, what he calls 'the capitalist world-economy' has spread over the entire world and entered into a cycle of 'expansion and contraction' whereby the centre of economic power shifts to different locations geographically. ${ }^{42} \mathrm{New}$ maps emerged, as a result of this capitalist world-system, tracing the trade in essentials rather than luxuries carried on within boundaries that lay between Eastern Europe on one side and Russia and the Turkish Balkans on the other as well as between 'the Christian and the Moslem Mediterraneans'. ${ }^{43}$

Venice was at the centre of this new 'capitalist world-system'. Fernand Braudel writes of 'the outstanding excellence of Venice's capitalism' and says that the world economy 'centered on Venice.' ${ }^{44}$ The English traveller Thomas Coryat in his Crudities Hastily Gobbled up in Five Moneth's Travels (1611) rhapsodizes about Venice as the 'Queene of Christendome' in regard of her incomparable situation, surpassing wealth, and most magnificent buildings'. He says of St Mark's Square that 'a man may very properly call it rather orbis than urbis forum, that is, a marketplace of the world'. ${ }^{45}$ Many reasons accounted for Venice's importance: its prime location; its proximity to the East through the Levant; its dexterity and ingenuity in finding alternate routes of access (Venice knocked on the gates of Egypt and Syria, for example, when the Mongol route was blocked in the 1340s). It also boasted of better contacts with Germany and Central Europe than any other Italian city. ${ }^{46}$ By the end of the fourteenth century all accepted Venice's primacy. In 1383 it occupied Corfu, 'the gateway to the Adriatic. ${ }^{47}$ In the first two decades of the fifteenth century it occupied Padua, Verona, Brescia, and Bergamo and was thus protected from the rest of the Italian city-states by a 'ring of towns and territories'. ${ }^{48}$ Its wealth was legendary: as early as 1423 , the receipts of the city of Venice alone came to over 750,000 ducats; the per capita income in the city, between 50 and 100 ducats, was enormous. Braudel compares the wealth of Venice, a mere city, to that of the kingdoms of France and Spain. ${ }^{49}$ The entire kingdom of France, arguably in a vulnerable state, could put together only one million ducats, but Venice's budget was equal to that of Spain (although what Spain means could be 'disputed,' as Braudel points out). ${ }^{50}$ From the early fifteenth century the focus was on ducats, gold, houses, and clothes. In the last years of the sixteenth century, the zecca, Venice's mint, was coining about 'two million ducats worth a year of gold and silver coins'. ${ }^{51}$ Venice's merchants firmly controlled all major commodity trades in the Mediterranean — grains, spices, Syrian cotton, wine, pepper, and, above all, salt. ${ }^{52}$ Other signs of Venice's riches 
lay in the city's powerful arsenal, the numerous galleys and cargo vessels it owned, and in the system of the galere da mercato: merchant vessels originally of 100 tons and later as large as 300 tons 'capable of carrying in their holds the equivalent of fifty cartloads of goods. ${ }^{53}$ While moving in and out of ports, they used oars. Otherwise they sailed like other vessels. The vessels were not the largest but were very safe, sailing in convoy and protected by 'archers and slingsmen'. ${ }^{44}$ Later, even cannons were put on board for defence. ${ }^{55}$

The Eastern frontier was difficult to ascertain because of the conquests of the Turks, but in the west, the whole of Europe was in Venice's hands, as were the Mediterranean and Constantinople until 1453. The Turks had not yet seized the coasts of Islamic countries. North Africa, Egypt, and Syria were open to Christian merchants. Spices, drugs, and silks were conveyed to Levant ports where western merchants waited, as routes running inland to the Red Sea and the Persian Gulf were closed to them. ${ }^{56}$

Venice became the universal warehouse of the world. The whole of Germany, for example, despite sanctions and restrictions, delivered to the merchants of Venice iron, hardware, fustian (mixture of cotton and linen), and, from the mid fifteenth-century onwards, increasing quantities of silver currency. ${ }^{57}$ All trade to and from Terraferma, all exports from Venice's islands in the Levant or cities in the Adriatic, even goods travelling to Sicily or England, had to pass through the port of Venice. No wonder, then, that Braudel states that the 'world economy centered on Venice. ${ }^{58}$

Venice was in a more advanced stage of commercial development than England; Jews had to staff and finance low-interest, non-profit lending institutions for the Christian poor. The Jews of Venice contributed to the economy not as usurers but as merchants. Venetian Jews were in reality closer to Shakespeare's Antonio than to his Shylock. With the development of an international, transEuropean economic network, the enmity between the merchant and the usurer, as demonstrated in Shakespeare's play, was not a reality. The contrast between Jew and Christian was a 'false dichotomy' as Shakespeare's England did not necessarily value the Italian merchant over the Jewish one. 59 'All men, specially strangers, have so much liberty there ... If thou be a Jew, a Turk, or believest in the devil (so thou spread not thine opinions abroad), thou art free from all controlment'. ${ }^{60}$ Venice was a meeting place for people of many nationalities and religions who enjoyed the freedom of wearing their national dress and speaking their own languages. Coryat writes that in St Mark's Square one might 'both see all manner of fashions of attire and heare all the languages of Christendome, besides those that are spoken by the barbarous Ethnickes'. ${ }^{61}$ 


\section{The Merchant of Venice: Structures of Antagonistic Difference}

The alternative title to The Merchant of Venice, 'The Jewe of Venyce', was used when The Jew of Malta was enjoying a return to popularity. ${ }^{62}$ Shakespeare's whole play, however, builds itself on sharp and distinct polarities, on structures of antagonistic difference rather than on similitude. Stephen Greenblatt enumerates some of these structures: Shakespeare's Venice exhibits conflicts between the old law and the new law, between justice and mercy, between revenge and love, between thrift and prodigality, between 'Jewish fiscalism and Gentile mercantilism' — in fact, between all the qualities commonly associated with Jew and Gentile. ${ }^{63}$ Even the cold, dark, and empty interiors of Shylock's house, where inmates are locked in and strangers are locked out, contrast with the music, the moonlight, and the sprawling gardens of Portia's home, the doors of which always stand hospitably open even to complete strangers. Shylock does not even trust his daughter to be home alone and orders Lancelot Gobbo to keep an eye on her as he leaves. Portia does not think twice about leaving her entire property in Belmont under the guardianship of Lorenzo, whom she has just met, as she travels to Venice. Antonio and Portia are liberal to a fault, even to strangers; they are quick to take a gamble. Shylock is cautious and frugal, parsimonious even with his only child.

The play establishes Venice as one of the most important trading centres. Shylock says about Antonio that he has an 'argosy bound to Tripolis, another to the Indies ... a third at Mexico, a fourth for England' (1.3.15ff). ${ }^{64}$ Salerio remarks that Antonio's ships carry spices and silks: 'scatter all her spices on the stream, / Enrobe the roaring waters with ... silks' (1.1.33-4). Shylock is, of course, not a merchant as is Marlowe's Barabas and as he would have been in early modern Venice, but a usurer.

The play gives the Rialto sufficient importance. Braudel says that 'All major business matters were therefore handled literally in the streets surrounding the bridge.' ${ }^{65}$ After waxing eloquent on the Rialto bridge, Coryat writes: 'The Rialto which is at the farther side of the bridge as you come from St. Marks, is a most stately building, The building being the Exchange of Venice, where the Venetian ... gentlemen and the merchants doe meete twice a day. ${ }^{66}$ If a merchant was deprived of his rights to the Rialto he was deprived of his livelihood. The Rialto makes an early appearance in the play. Shylock, on his first appearance, says that he has heard all Antonio's news on the Rialto: 'I understand moreover upon the Rialto' (1.3.16-17). Later, he asks Antonio, 'What news on the Rialto?' (33), and in the course of their conversation slyly reminds Antonio that 'many a time 
and oft / In the Rialto you have rated me / About my money and my usances' (102-4).

Apart from the importance it gives to the Rialto, Shakespeare's play also mirrors the connection between credit and usury in the world of Venice. The Monte di Carita were the Christian lending institutions that provided interest-free loans in Venice. Shakespeare depicts Antonio as a sort of personalized and individualized Monte di Carita who freely lends money and does not charge any interest, and for this he earns Shylock's wrath. '[I]n low simplicity / He lends out money gratis, and brings down / The rate of usance here with us in Venice' (1.3.38-40), grumbles Shylock. Antonio is aware of Shylock's feelings and admits it with some degree of glee as those he helps out with an interest-free loan are often Shylock's debtors: 'I oft delivered from his forfeitures / Many that have at times made moan to me. / Therefore he hates me' (3.3.22-4). ${ }^{67}$

Venetians accepted the legitimacy of credit. Interest rates could be very high, as high as twenty per cent, and 'such loans might be accompanied by pledges which remained in the clutches of the lender'. ${ }^{68}$ The notion of the pledge given by Antonio to Shylock thus had roots in actual Venetian practice. Although Shakespeare's play quite unilaterally condemns usury, pragmatic Venice saw it as a necessary evil. Venice admitted the first consortium of Jewish usurers as early as 1382; they lent money to small borrowers and occasionally even to patricians. Even as he asks Shylock for a loan, Antonio haughtily scoffs that this request will not change his behaviour or his attitude: 'I am as like to call thee so [dog] again, / To spit on thee again, to spurn thee too' (1.3.125-6).

The one aspect of early modern Venice that Shakespeare captures sharply is the spirit of adventure, particularly the adventure that arises out of trade and fiscal matters, the willingness to take risks which was in part the cause of Venice's financial strength, and the abiding spirit of venture capitalism. The entire Venetian population advancing money to merchant venturers, the 'constantly available and spontaneously offered supply of credit', made merchant operations possible without long-term companies with capital funds. ${ }^{69}$

Bassanio is not the least bit ashamed to say that he has lived beyond his slender means and that he dreams impossible dreams of wooing the heiress Portia: 'How much I have disabled mine estate / By something showing a more swelling port / Than my faint means would grant continuance' (1.1.123-5). He mentions with pride his technique of meeting loss with greater risk-taking in an effort to regain his lost fortunes: 
In my schooldays, when I had lost one shaft,

I shot his fellow of the selfsame flight

The selfsame way, with more advised watch,

To find the other forth; and by adventuring both,

I oft found both.

This sense of 'adventuring', so typical of Venetians, makes Bassanio not in the least abashed to ask for a huge loan from Antonio even though he, Bassanio, has shown no evidence of fiscal responsibility. Antonio, knowing full well the spendthrift ways of his friend, nevertheless generously offers all that he has: 'My purse, my person, my extremest means / Lie all unlocked to your occasions' (138-9). Not having ready funds at his disposal does not inhibit Antonio from asking for a loan:

all my fortunes are at sea,

Neither have I money, nor commodity

To raise a present sum. Therefore go forth -

Try what my credit can in Venice do.

The fact that Antonio readily agrees to Shylock's strange conditions, knowing full well that the moneylender is his enemy, is also an expression of the willingness to take huge risks, the 'adventuring', that was so much a part of Venice's financial climate. Portia mirrors Antonio's generosity. Hearing of the latter's troubles, the amount of three thousand ducats that he owes Shylock, she declares to Bassanio:

Pay him six thousand, and deface the bond.

Double six thousand and then treble that,

Before a friend of this description

Shall lose a hair through Bassanio's fault.

And this assertion comes without Portia ever setting eyes on Antonio. Like father, like daughter: Portia's father gambles with his daughter's fortunes and her future happiness by setting up the casket 'lottery', as Nerissa puts it, and suitors come from far and wide to try their luck despite the huge odds and high stakes (1.2.25). As Portia reminds Morocco, 'if you choose wrong / Never to speak to lady afterward / In way of marriage' (2.1.40-2).

While Shakespeare's depiction of the mercantile and financial adventurism of Venice is accurate, his play does not mirror the cosmopolitan nature of early modern Venice. In The Merchant of Venice, xenophobia, difference, distinction, and discrimination rule. The harsh dichotomies and rifts bely the few glimpses we get 
of an impartial Venice, as in these words Antonio speaks in response to Solanio's remark that the duke of Venice would never allow Shylock the savage terms of his bond: 'The Duke cannot deny the course of law', says Antonio,

For the commodity that strangers have

With us in Venice, if it be denied,

Will much impeach the justice of the state,

Since that the trade and profit of the city

Consisteth of all nations.

Shylock, too, knows that to refuse his demand would bring into jeopardy the much-lauded impartiality of Venice's law courts and their lack of religious or ethnic prejudice. This knowledge is why he can confidently persevere with his absurd demand in the trial scene:

The pound of flesh ...

...' 'Tis mine, and I will have it.

If you deny me, fie upon your law:

There is no force in the decrees of Venice.

But these glimpses are few and far between, and the spirit of impartiality and lack of discrimination remain in the realm of the theoretical and the ideal rather than being put into practice. Instead, bitter feuds and differences dominate the play. Shylock and Antonio, both residents of Venice, are at loggerheads and throw the most colourful aspersions on each other's religions and customs. 'I hate him for he is a Christian' (1.3.37), says Shylock bluntly, and Antonio, even while asking Shylock for a loan, arrogantly declares, 'I am as like to call thee so [dog] again, / To spit on thee again, to spurn thee too' (125-6). Shylock professes a preference for the complete separation of Christian and Jew within Venice, even if they have financial dealings: 'I will buy with you, sell with you, talk with you ... but I will not eat with you, drink with you, nor pray with you' (31-3). In fact, the truth was otherwise. Coryat writes of his visit to a Venetian synagogue and his long conversations with Jewish rabbis about matters of faith in Venice. He praises the appearance of certain Venetian Jewish men ('most elegant and sweet featured persons') and women ('whereof some were as beautiful as ever I saw'), the latter as heavily bejeweled as the 'English Countesses'. ${ }^{70}$ Quite a contrast are Portia's geographically and culturally insular remarks about her suitors - the Neapolitan prince who is a 'colt' (1.2.35), the County Palatine who 'doth nothing but frown' (40), the French lord, Monsieur le Bon, who is 'every man in no man' (50), Falconbridge, the young baron of England, who 'hath neither Latin, French, 
nor Italian' and is thus no better than 'a dumb show' $(58,61)$ - that culminate in the explicitly racist comment about the duke of Morocco, once he chooses the wrong casket: 'Let all of his complexion choose me so' (2.7.79). This insularity is not a true reflection of cosmopolitan Venice, making alliances with faiths and cultures and languages entirely different from its own. The imaginary Belmont is not Venice, but instead close enough to Venice to imbibe some of its renowned tolerance of difference. ${ }^{71}$

The trial scene (4.1) brings these divisions out in sharp focus; indeed, it showcases them. Shylock's demand for rigorous justice comes across as inhuman, bestial, and 'wolvish', and contrasts sharply with the Christians' plea for mercy. The Duke begins by describing Shylock as a 'stony adversary, an inhuman wretch' (4). Graziano describes Shylock's desire for a pound of Antonio's flesh as 'wolvish, bloody, starved, and ravenous' (137). Antonio stoically says that he will 'oppose / My patience to his [Shylock's] fury' (9-10). The Christian characters repeatedly refer to the need for mercy: 'How shalt thou hope for mercy, rend'ring none?' asks the Duke of Shylock (86); Portia reminds Shylock that mercy 'is an attribute to God himself' and that 'in the course of justice none of us / Should see salvation' (190, 194-5). Shylock, however, will have none of these Christian, New Testament virtues. His desire is for justice, a justice that he sees in the Old Testament vengeful spirit of an eye for an eye: 'I stand for judgment. Answer: shall I have it?' (102).

We see that Marlowe in his depiction of Malta draws a picture in which one is hard put to distinguish the virtuous from the maleficent. We are in a world close to the one King Lear describes on the heath: 'See how yon justice rails upon yon simple thief. Hark in thine ear: change places and handy-dandy, which is the justice, which is the thief? ... The usurer hangs the cozener' (King Lear 4.6.14850, 159). ${ }^{72}$ Distinctions blur and people use the same Machiavellian stratagems against one another; if one is pure and unsullied (as is Abigail) one does not survive. ${ }^{73}$ Marlowe deliberately resists using the Great Siege as a climax for his play, suffused as the grand narrative of that siege is with the tale of Christian heroism against the Muslim infidel. In contrast, Shakespeare's play, while faithfully recreating the financial and mercantile adventurism and risk-taking that was so much a part of early modern Venice, does not do justice to Venetian society's famed tolerance towards religious and ethnic minorities. The Merchant of Venice underlines difference and weighs the scales of virtue heavily in favour of the Christians, ambiguous and ambivalent though many of their actions may be, as opposed to the marginalized and demonized Jewish usurer. 


\section{Notes}

1 I agree with Irving Ribner when he says the fact 'That The Jew of Malta exerted much influence on The Merchant of Venice is a questionable proposition' but I strongly disagree with his argument that 'The Merchant of Venice is a comedy of affirmation whose subject is love, while The Jew of Malta is a tragedy of defeat and negation whose subject is hatred'. Ribner, 'Marlowe and Shakespeare', Shakespeare Quarterly 15.2 (1964), 45, 46, https://doi.org/10.2307/2867874. Shakespeare's play contains as much hatred as Marlowe's, as I shall argue in my essay.

2 Cecil Roth, 'The Jews of Malta', Transactions (Jewish Historical Society of England) 12 (1928-31), 188, https://doi.org/10.1086/483649.

3 Ibid, 189.

4 Ibid, 213.

5 See Lisa Hopkins, Christopher Marlowe: A Literary Life (Basingstoke, 2000), 86-9.

6 Roth, 'Malta', 213.

7 Ibid.

8 Hopkins, Christopher Marlowe, 86-9.

9 Ibid.

10 Ibid.

11 Stephen J. Greenblatt, 'Marlowe, Marx and Anti-Semitism', Critical Inquiry 5.2 (1978), 298, https://doi.org/10.1086/447990.

12 Roth, 'Malta', 188. Brett D. Hirsch quotes Anthony Bale to explain his preference for the non-hyphenated term 'antisemitism' over 'anti-Judaism' or 'anti-Semitism' because according to him, 'outside linguistics there is no such thing as a Semite; it is only a negative category forced onto Jews, and others'. Hirsch, 'Jewish Questions in Robert Wilson's The Three Ladies of London', Early Theatre 19.1 (2016), 38, http:// dx.doi.org/10.12745/et.19.1.2544. The term used in this essay is, of course, a quotation from Roth.

13 Roth, 'Malta', 189.

14 Roth says that the number of 'aliens' in Queen Elizabeth's London increased from 3000 to 10,000; among them was the Marrano community, whose hundred or more members included 'a few persons of outstanding ability and some prominence in public life'. Cecil Roth, A History of the Jews in England (Oxford, 1941), 139, 140 Marranos or Iberian Jews, unlike the new Christians, were 'persons avowing Christianity, but covertly continuing to live as Jews' (Peter Berek, 'The Jew as Renaissance Man', Shakespeare Quarterly 51.1 [1998], 132, https://doi.org/10.2307/2901665). Hirsch writes that 'a web of complex, contradictory, and shifting cultural, social, 
theological, and political associations informed the word "Jew" in Elizabethan England'. On the one hand they were God's chosen people with an access to scriptures free from 'Catholic impurity and mistranslation'; on the other hand they were stigmatized in gospel and Christian sermon as children of the devil, 'morally abject, physically monstrous and socially aberrant' ('Jewish Questions', 38, 39).

15 All quotations from The Jew of Malta are from J.B. Steane, ed., Christopher Marlowe: The Complete Plays (1969; Harmondsworth, 1973), 341-430.

16 Roth, 'Malta', 207.

17 Ibid, 208.

18 Ibid, 212.

19 Hirsch, 'Jewish Questions', 42, quotes Nicolas de Nicolay's bestselling travel narrative of 1567 translated and published in English as The Nauigations, Peregrinations and Voyages, Made into Turkie (London, 1585) in stating the types of information the Jews shared with the Turks: 'diuers inuentions, craftes and engines of warre, as to make artillerie, harquebuses, gunne pouder, shot, and other munitions'.

20 Roth, 'Malta', 216.

21 Ibid.

22 Ibid, 214-15.

23 Ibid, 216.

24 See Howard S. Babb, 'Policy in Marlowe's The Jew of Malta', English Literary History 24.2 (1957), 90, https://doi.org/10.2307/2871823.

25 Roth, 'Malta', 213.

26 See Virginia Mason Vaughan, 'The Maltese Factor: The Poetics of Place in The Jew of Malta and The Knight of Malta', in A Companion to the Global Renaissance: English Literature and Culture in the Era of Expansion, ed. Jyotsna G. Singh (Chichester, 2009), 345.

27 The English traveller's account is dated ca 1663, later than Marlowe's play, but the phenomenon was present at the time of Marlowe's play and earlier.

28 Roth, 'Malta', 214.

29 Mason Vaughan, 'Maltese Factor', 345.

30 While Emma Smith questions whether Elizabethan England necessarily regarded Jews as negative characters, a commonly held belief she ascribes to Henry Irving's influential nineteenth-century production of The Merchant of Venice (Smith, 'Was Shylock Jewish?', Shakespeare Quarterly 64.2 (2013), 188-219, https://doi.org/10.1353/ shq.2013.0034), Hirsch, 'Jewish Questions', questions the integrity critics usually attribute to Gerontus, the leading Jewish character in Robert Wilson's The Three Ladies of London.

31 Babb, 'Policy', 89. 
32 Steane, in his edition of Marlowe's plays, remarks that 'Here and in some other places Quarto has “bashaws” (Christopher Marlowe: The Complete Plays, 597).

33 Catherine Minshull argues that Ferneze and not Barabas is the true Machiavellian character in the play as he pays attention to the letter of religion while disregarding its spirit; he wears a mask of virtue and piously condemns all evil actions; he habitually breaks faith with people; he never trusts former enemies; he 'demonstrates the ability to adapt rapidly to different circumstances'. Minshull, 'Marlowe's "Sound Machevill”', Renaissance Drama ns 13 (1982), 48, https://doi.org/10.1086/rd.13.43264628. I argue that with regard to Machiavellianism the characters of Marlowe's play exhibit a difference in degree rather than kind.

34 See Lisa Hopkins, "Malta of Gold” Marlowe, The Jew of Malta, and the Siege of 1565', $\operatorname{Re}$ (Soundings) 1.2 (1997), http://shura.shu.ac.uk/1294/.

35 See Stanley Fiorini, 'Malta in 1530', in Hospitaller Malta 1530-1798, ed. Victor Mallia-Milanes (Msida, Malta, 1993), 141-2, as cited by Hopkins, Christopher Marlowe, 86-9.

36 Ernle Bradford, The Great Siege: Malta 1565 (1961; Harmondsworth, 1964), 180-1, cited by Hopkins, Christopher Marlowe, 86-9.

37 Joseph Attard, The Knights of Malta (Marsa, Malta, 1992), 69, cited by Hopkins, Christopher Marlowe, 86-9.

38 Mason Vaughan, 'Maltese Factor', 346.

39 The Knight of Malta (1647), collaboratively authored by John Fletcher, Philip Massinger, and Nathan Field, was written nearly thirty years after Marlowe's play and is tragicomic in mode (ibid, 348). The focus is not on Malta as a bastion of heroic Christianity but on a sustained test of corruption for the men and sexual purity for the women. The play unfolds an almost domesticated intrigue and counter-intrigue with the sensual Abdella (Fletcher, Massinger, and Field blithely give a female Muslim character a man's name, Abdulla) plotting with the French knight Montferrat to bring about the downfall of the Spanish protagonist Miranda, a Knight of the Order, and defame the resolutely chaste Oriana. Both Abdella and Montferrat are exposed at the end of the play and expelled from Malta by Valletta as 'rotten, / Corrupted, and contagious'. Fletcher, Massinger, and Field, The Knight of Malta, 5.2.214-15, in The Dramatic Works in the Beaumont and Fletcher Canon, ed. Fredson Bowers (Cambridge, 1970). For the most part the play unfolds in simple binaries and the characters are either impossibly virtuous or outrageously villainous. It exhibits no attempt to puncture the heroic rhetoric associated with the Great Siege or to present the forces of evil as insidious and omnipresent as in Marlowe's play. Another play, Soliman and Perseda, published anonymously in 1592-3 but probably written around 1588, now ascribed to Thomas Kyd, Marlowe's onetime roommate, tells the story of 
the somewhat mercurial emperor of Turkey, Soliman, and the effect that his love for Perseda has on his friendship with Erastus, a knight of Rhodes and Perseda's childhood sweetheart. The play initially highlights the admiration the Christian Erastus has for Soliman, who granted him refuge in Constantinople when he was fleeing from Rhodes on a murder charge ('To Turkey I must go ... / The people warlike, and the King renowned / For all heroical and kingly virtues' [2.1]), admiration that both Soliman and his general Brusor reciprocate ('And had he worshipped Mahomet for Christ, / He might have borne me throughout the world' says Brusor of Erastus after seeing him perform victoriously in a tournament [3.1]). Once Solimon falls in love with Perseda, however, the usual tussle between deceitful and barbaric Muslim antagonist and valiant and virtuous Christian protagonist is showcased. Erastus is strangled on a false charge of treason, Perseda, in male martial disguise, is killed by Soliman, but not before she bestows on him a poisoned kiss, thereby sealing his fate. Soliman becomes, in Perseda's words, 'perjured and inhuman', a man who has 'betrayed the flower of Christendom' (5.4). See Soliman and Perseda, ed. Robert Brazil, http://www.elizabethanauthors.org/soli101.htm. Kyd thus does not ultimately maintain the initial promise of impartial liberalism even though he takes pains to emphasise how the Turks were generous and fair employers of the 'janissaries', troops drawn from the mostly Christian population. As Laurence Publicover observes, it was the 'policy' of the Ottoman empire to employ non-Turks and even non-Muslims 'with martial or administrative talent'. Publicover, Dramatic Geography: Romance, Intertheatricality, and Cultural Encounter in Early Modern Mediterranean Drama (Oxford, 2017), 99.

40 See Immanuel Wallerstein, The Modern World-System II: Mercantilism and the Consolidation of the European World Economy, 1600-1750 (New York, 1980), 7.

41 Ibid, 7-8.

42 Ibid.

43 Ibid, 9.

44 See Fernand Braudel, Civilization and Capitalism 15 $5^{\text {th }}-18^{\text {th }}$ Century, trans. Sian Reynolds (Berkeley and Los Angeles, 1992-), 3.118, 124.

45 Ibid, 3.125.

46 See Thomas Coryat, Coryat's Crudities: Hastily gobbled up in five moneth's travels (1611; Glasgow, 1905).

47 Braudel, Civilization, 3.119.

48 Ibid.

49 Ibid, 3.120.

50 Ibid.

51 Ibid, 3.122. 
52 Ibid, 3.123.

53 Ibid, 3.126.

54 Ibid.

55 Ibid.

56 Ibid, 3.124.

57 Ibid, 3.125.

58 Ibid, 3.124.

59 See Walter Cohen, 'The Merchant of Venice and the Possibilities of Historical Criticism', English Literary History 49.4 (1982), 765-89, https://doi.org/10.2307/2872897. Cohen writes that 'the very contrast between the two occupations [Jewish usurer and charitable Christian merchant] can be seen as a false dichotomy' and that 'Shakespeare's preference for an Italian merchant over a Jewish usurer' was not 'universally shared at the time' (771).

60 See William Thomas, The History of Italy (1549), ed. George B. Parks (Ithaca NY, 1963), 83.

61 Coryat, Crudities.

62 See Janet Clare, Shakespeare's Stage Traffic: Imitation, Borrowing and Competition in Renaissance Theatre (Cambridge, 2014), 14.

63 Greenblatt, 'Marlowe', 293-4.

64 All quotations from The Merchant of Venice are from The Norton Shakespeare, ed. Stephen Greenblatt et. al. (New York and London, 1997), 1081-1145.

65 Braudel, Civilization, 3.129.

66 Coryat, Crudities.

67 Greenblatt compares Antonio's actions to the 'monte di carita', Christian 'lending institutions' that provided interest free loans to Christians and tried to diminish the power of Jewish moneylenders (Greenblatt, 'Marlowe', 294). Cohen, however, using the term 'Monti di Pietà' — banking institutions to provide interest free loans to the poor - says there were no such institutions in fifteenth-century Venice ('Possibilities of Historical Criticism', 770).

68 Braudel, Civilization, 3.129.

69 Ibid, 130.

70 Coryat, Crudities.

71 Violet M. Jeffery, quoting Coryat's Crudities, conjectures that Belmont must be on the banks of the river Brenta, the river on which Coryat travelled down to Venice and glimpsed many 'goodly faire houses and palaces of pleasure' on either side. Jeffery, 'Shakespeare's Venice', Modern Language Review 27.1 (1932), 28, https://doi. org/10.2307/3716217. Jeffery mentions the fact that Portia suggests that Belmont is 
twenty miles from Venice ('and therefore haste away, / For we must measure twenty miles today', Portia tells Nerissa when they set out for Venice [3.4.84-5]).

72 Quotations from King Lear are from the Arden Shakespeare Second Series, ed. R.A. Foakes (Surrey, 1997). Lisa Hopkins, “Lear, Lear, Lear!” Marlowe, Shakespeare and the Third', The Upstart Crow 16 (1996), notes many similarities between Sidney's Arcadia and Apology for Poetry, Marlowe's Tamburlaine the Great, and Shakespeare's King Lear, with regard to notions of historiography and religious belief, but above all 'with the nature and workings of love' (120). According to Hopkins, King Lear stands between Scythia and Arcadia, 'between the ancient world's most optimistic and most pessimistic views of the human condition' (115). Apart from a fleeting reference, The Jew of Malta finds no mention in this article.

73 Ribner contrasts Abigail and Jessica and takes this contrast to be a significant marker about the difference between Shakespeare and Marlowe: 'Jessica is an agent of her father's redemption while Abigail is the sacrificial victim of her father's villainous perdition. In these differences - far greater than anything the two plays have in common - is a measure of the difference between the two poets' ('Marlowe and Shakespeare', 48-9). Jessica's apathy towards her father but not to his wealth, illustrated through all her cold-blooded and avaricious actions and highlighted in the callous barter of her dead mother's ring for a monkey, is, to my mind, one of the most effective means of arousing sympathy for Shylock. As for Ribner's comment that The Merchant of Venice is a play about love and The Jew of Malta a play about hatred (46), in my mind hatred is clearly present and redemption plays no role in Shakespeare's play unless one is completely blind to the evil of forced conversion. As for love, there is romantic love, but only for some, in The Merchant of Venice. 
